\section{ON THE PREY OF THE COLLARED SCOPS OWL OTUS BAKKAMOENA (PENNANT) AT AUROVILLE, PONDICHERRY}

\author{
Boris Verzhutskii ${ }^{1}$ and Mario Eric Ramanujam ${ }^{2}$ \\ ${ }^{1}$ Entomologist, "Palmyra" Auroville, Pondicherry 605111, India \\ ${ }^{2}$ Research associate, Gratitude Avian Rehabilitation, Auroville, \\ Pondicherry 605101, India. \\ Emails: ${ }^{1}$ gratitude@auroville.org.in; ${ }^{2}$ aranya@auroville.org.in
}

The food of Otus bakkamoena has been described as beetles, grasshoppers and other insects, lizards, mice and small birds (Ali \& Ripley, 1969); large insects, lizards, mice (Ali, 1977); and beetles, other insects; occasionally mice and lizards (Ali, 1996).

This study in two different areas simply aimed to discern the prey base of the species. In depth ecological impacts - viz. prey biomass, seasonal population fluctuations, etc. were not undertaken.

Two different ravine cum re-afforested plantation areas in the Auroville bioregion constituted the study sites: 'Aspiration', about a kilometre from the seashore, entirely forested with an average tree height of 10m. (afforestation since 1977), and 'Aranya', about $12 \mathrm{~km}$ from the seashore in the vicinity of Ousteri Lake, with an average tree height of $5 \mathrm{~m}$ (afforestation since 1993) and the dominant vegetation being grasses - Aristida sp., Paspalum sp., Heteropogon contortus, etc. (Fig. 1).

Pellets were gathered in the vicinity of the habitual roosting trees of the owls - 36 in Aspiration and 54 in Aranya - from March 2001 to February 2002. Binocular microscope and established literature on insects (Heinrich, 1994; Borror, 1992; Mani, 1990) allowed an analysis of all arthropod remains; reptiles were distinguished from scales and the rodent from its characteristic skeletal features.

The percentage of particular components of the food of the owl was divided into four categories according to the frequency of occurrence (Kumar, 1985): basic food - prey species occurring with a frequency of over $20 \%$; constant food - prey species occurring with a frequency between 5-20\%; supplementary food - prey species occurring with a frequency between $1-5 \%$; chance food - prey species occurring with a frequency below $1 \%$.

Analysis disclosed the basic food to consist of Orthoptera and Isoptera; constant food Coleoptera (Scarabaeldae, Lucanidae, etc.); supplementary food Araneae, Hemiptera, Hymenoptera, Blattaria, Reptilia; and chance food Gastropoda, Scorpionida,
Lepidoptera (imagos \& larvae), Odonata, Diptera and Rodentia. No birds were evident among the 2,684 prey items identified in pellets.

A marked variation, especially of basic food was evident between the two areas of contrasting vegetational types - in Aranya the Orthoptera predominated $51.51 \%$ in comparison to $6.96 \%$ in Aspiration.), whereas in Aspiration the Isoptera was the primary food (70.66\% compared to $8.91 \%$ in Aranya). For further details refer the Table 1.

The reason for the owl predating on different items in different areas has a direct bearing. on the habitats in question - a casual perusal shows termites proliferating in old growth plantations and Orthopterans in grasslands. This opportunistic feeding habit is not confined to Otus bakkamoena alone; it has been commented upon in the Barn owl Tyto alba (Czamecky et al., 1995; Herrera \& Jaksic, 1980; Ruprecht, 1964, 1971, 1979), Long-eared Owl Asio otus (Czarnecky, 1956), and Spotted Owlet Athene brama (Kumar, 1985).

\section{Acknowledgements}

Special thanks are due to D.C. Worden, J. Brooks, P.M. Sahu, D. Saravanan and S. Mani for facilitating this study in many ways, and of course 'Spencer' for his constant presence in our thoughts.

\section{References}

Ali, S. and S.D. Ripley (1969). Handbook of the Birds of India and Pakistan. Oxford University Press 3: 266

Ali, S. (1977). Field Guide to the Birds of the Eastern Himalayas. Oxford University Press, 57pp.

Ali, S. (1996). Book of Indian Birds. $12^{\text {th }}$ revised edition, Oxford University Press, 184pp.

Borror, D. (1992). An Introduction to the Study of Insects. Harcourt Brace College Publishers, USA, 876pp.

Czarnecky, Z., T. Gruszynska and E. Smoknska (1955). Badania \& Skladem pokannu plomykowki (Tyto alba guttata) $w$ latach $1950-52 \mathrm{w}$ wojewodztwie poznam skim. Ibidem 16(3): 1-39

Czarnecky, Z. (1956). Obserwacje nad biologia sowy uszatej (Asio otus otus L.) Oisb, Tow pzyj. Nauk, wydz, Mat przyr. Prod. Kom. Biol. 18(4): 1-42.

Heinrich, E. (editor) (1994). Biology and Management of Rice Insects. 780pp.

Herrera, C.M. and F. Jaksic (1980). Feeding ecology of the Barn owl in central Chile \& Southern Spain. A comparative study. The Auk 97: 760-767

Kumar, T.S (1985). The life history of the Spotted owlet (Athene brama brama Temminck) in Andhra Pradesh, pp. 97-108. Raptor Research Centre, Hyderabad.

Mani, M. (1990). General Entomology. Oxford \& IBH Publishing. New Delhi, 912pp.

Ruprecht, A. (1 964). Analiza skladu pokarmu polmykowki Tyto alba guttata (C.L.Br.) Z Aleksandrowa kuj., ciechocinka 1 raciazka w latach 1960-61. Zesz. Nauk.Uniw. Mikolaja kopernika Torunia Biol. (Torum pol.) 7: 45-66.

Ruprecht, A. (1971). O Skladzlc pokan-nu polmykowki(Tyto alba guttata)z Nieszawy (Noj Bydgoski). Przyroda polski Zachodnifj 9: 72-78.

Ruprecht, A. (1979). Food of Barn Owl, Tyto alba guttata (C.L.Br.) from Kujawy. Acta Ornithologica 19: 493-511. 
Table 1. The prey of Otus bakkamoena in two areas of Auroville from Mar 2001 to February 2002.

\begin{tabular}{|c|c|c|c|c|c|c|c|c|c|}
\hline \multirow[t]{2}{*}{ Prey } & \multicolumn{3}{|c|}{ Aranya } & \multicolumn{3}{|c|}{ Aspiration } & \multicolumn{3}{|c|}{ Summary } \\
\hline & Total & & Category & Total & $\%$ & Category & Total & $\%$ & Category \\
\hline Gastropoda(Snails) & 6 & 0.52 & OF & 2 & 0.12 & OF & 8 & 0.29 & OF \\
\hline Scorpionida (Scorpions) & 1 & 0.08 & OF & - & - & - & 1 & 0.03 & OF \\
\hline Araneae (Spiders) & 77 & 6.79 & $\mathrm{CF}$ & 46 & 2.96 & SF & 123 & 4.58 & SF \\
\hline Orthoptera (Grasshoppers \& Crickets) & 629 & 55.51 & $\mathrm{BF}$ & 108 & 6.96 & CF & 737 & 27.45 & $\mathrm{BF}$ \\
\hline Isoptera(Termites) & 101 & 8.91 & $\mathrm{CF}$ & 1096 & 70.66 & $\mathrm{BF}$ & 1197 & 44.59 & $\mathrm{BF}$ \\
\hline Hemiptera (Bugs) & 59 & 5.20 & $\mathrm{CF}$ & 7 & 0.45 & OF & 66 & 2.45 & SF \\
\hline Coleoptera (Beetles) & 70 & 6.17 & $\mathrm{CF}$ & 161 & 10.38 & $\mathrm{CF}$ & 231 & 8.60 & $\mathrm{CF}$ \\
\hline Lepidoptera (Moth imagos) & 7 & 0.61 & OF & 1 & 0.06 & OF & 8 & 0.29 & OF \\
\hline Larva & 4 & 0.35 & OF & 7 & 0.45 & OF & 11 & 0.40 & OF \\
\hline Hymenoptera (Bees, Wasps \& Ants) & 79 & 6.97 & $\mathrm{CF}$ & 35 & 2.25 & SF & 114 & 4.24 & SF \\
\hline Odonata(Dragonflies) & 11 & 0.97 & OF & - & - & - & 11 & 0.40 & OF \\
\hline Blattaria (Cockroaches) & 49 & 4.32 & SF & 50 & 3.22 & SF & 99 & 3.68 & SF \\
\hline Diptera (Flies) & 1 & 0.08 & OF & 9 & 0.58 & OF & 10 & 0.37 & OF \\
\hline Reptilia & 38 & 3.35 & SF & 29 & 1.86 & SF & 67 & 2.49 & SF \\
\hline \multirow[t]{2}{*}{ Rodentia (Mus.sp.) } & 1 & 0.08 & 0 & - & - & - & 1 & 0.03 & OF \\
\hline & 1,133 * & & & 1,551 ** & & & 2,684 & & \\
\hline
\end{tabular}

* prey items in 54 pellets; ** prey items in 36 pellets.

Categories: Basic Food - BF (>20\%); Constant food - CF (5-20\%); Supplementary food - SF (1-5\%); Chance food - OF (<1\%)

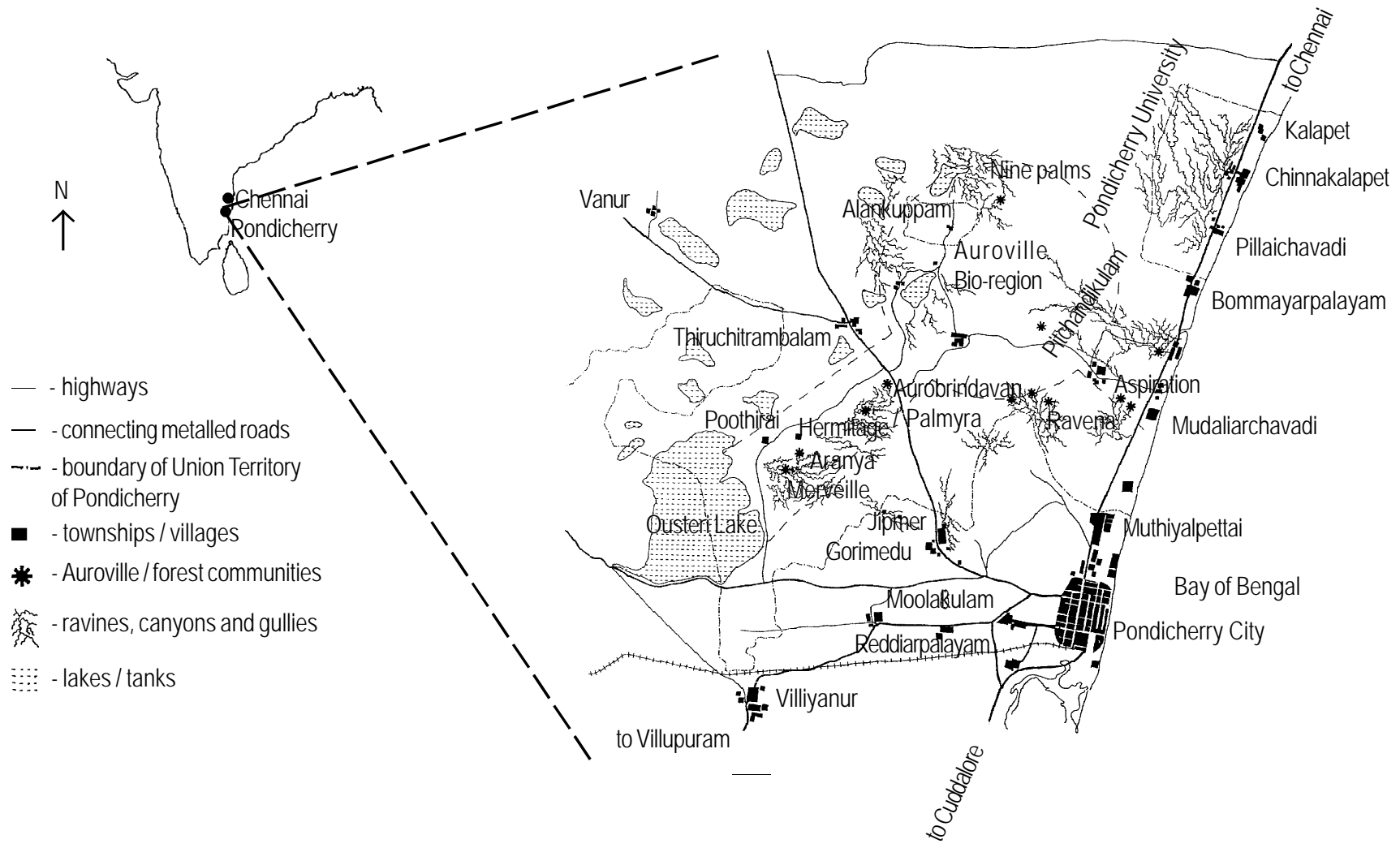

Figure 1. Map showing study sites Aranya and Aspiration 